\title{
PENGARUH METODE BERMAIN PERAN TERHADAP AKTIVITAS BELAJAR SISWA SEKOLAH DASAR PADA MATA PELAJARAN BAHASA INDONESIA
}

\author{
Sukristin $^{1}$, Indri Claudya ${ }^{2}$ \\ ${ }^{1}$ Dosen STKIP Melawi Kampus Wilayah Perbatasan Entikong \\ ${ }^{2}$ Mahasiswa Program Studi Pendidikan Sekolah Dasar \\ Jln. Kuari Yayasan Lintas Batas Kecamatan Entikong Kabupaten Sanggau \\ sukristintin@gmail.com,indrir564@gmail.com
}

\begin{abstract}
Abstrak: Latar Belakang dalam penelitian ini adalah kurangnya aktivitas belajar siswa pada saat pembelajaran sehingga tidak efektif. Penelitian ini bertujan untuk mengetahui pengaruh metode bermain peran terhadap aktivitas belajar siswa. Penelitian ini merupakan penelitian kuantitatif dengan metode penelitian eksperimen (Pre Experimental Design) dengan menggunakan desain penelitian One-Group Design. Teknik pengumpulan data menggunakan teknik kuesioner dan dokumentasi. Instrumen penelitian dalam penelitian ini menggunakan instrumen angket. Teknik analisis data menggunakan teknik analisis deskriptif kuantitatif. Pengujian hipotesis dalam penelitian ini menggunakan uji wilcoxon. Hasil uji wilcoxon memperoleh, $\mathrm{W}_{\text {hitung }}$ sebesar 129 sedangkan $\mathrm{W}_{\text {tabel }}$ senilai 208, berarti $\mathrm{W}_{\text {hitung }}<\mathrm{W}_{\text {tabel }}$, maka $\mathrm{H}_{\mathrm{o}}$ ditolak dan $\mathrm{H}_{\mathrm{a}}$ diterima. Hal ini menunjukan bahwa metode bermain peran dapat mempengaruhi aktivitas belajar siswa. Dengan nilai $\mathrm{W}_{\text {hitung }}<\mathrm{W}_{\text {tabel, }}$ maka metode bermain peran memberikan pengaruh yang lebih baik terhadap aktivitas belajar siswa dibandingkan sebelum diterapkannya metode bermain peran membuat aktivitas siswa menjadi meningkat.
\end{abstract}

Kata Kunci: Metode Bermain Peran, Aktivitas Belajar.

\begin{abstract}
: the background of this research is the lack of student's learning activity in the learning process so that the learning is not effective enough. The aim of this research is to find out the effect of role playing method toward student's learning activity. It is a qualitative research which use experiment research (Pre Experimental Design) and One-Group Design. The technique of data collection used questioner and documentation. The instrument of this research used the questioner sheet. The technique of data analysis used quantitative descriptive analysis technique. Hypothesis test of this research used Wilcoxon test. The result of Wilcoxon test showed that $\mathrm{W}$ amounted to 129 and $\mathrm{W}$ table was 208 , it means $\mathrm{W}_{\text {significant }}<\mathrm{W}_{\text {table, it }}$ means $\mathrm{H}_{\mathrm{o}}$ rejected and $\mathrm{H}_{\mathrm{a}}$ accepted. It showed that the role playing method affects the student learning activity. Based on the $\mathrm{W}_{\text {significant }}<\mathrm{W}_{\text {table, }}$, so the role playing method affects the student's learning activity better with the comparison before the method applied.
\end{abstract}

Key Word: role playing method toward student's learning activity

$\mathrm{B}$ ahasa Indonesia merupakan salah satu mata pelajaran terpenting yang ada di sekolah yang bertujuan untuk mengembangkan kemampuan Berbahasa Indonesia siswa. Pembelajaran Bahasa
Indonesia diharapkan dapat membantu siswa mengenal dirinya, budayanya dan budaya orang lain, mengemukakan gagasan dan perasaannya. Dalam pembelajaran Bahasa Indonesia, terdapat beberapa 
keterampilan yang harus dikuasi oleh siswa yaitu, keterampilan menulis, membaca, menyimak, dan berbicara, namun tidak hanya keterampilan yang terdapat di dalam Bahasa Indonesia tetapi terdapat juga sastra yang harus diketahui dan dipahami oleh para siswa.

Berdasarkan pengamatan yang peneliti lakukan pada tanggal 28 Oktober 2018 di kelas IV Mis Al-Wardah Balai Karangan, ditemukan beberapa masalah pada pembelajaran Bahasa Indonesia yaitu, kurangnya keaktifan siswa di kelas, sehingga membuat, pembelajaran hanya berfokus pada siswa yang aktif sehingga siswa yang lain merasa tidakdiperhatikan, hal ini terjadi karena ketika ditanya hanya siswa itu saja yang menjawab pertanyaan yang diajukan oleh guru sedangkan siswa yang lain hanya diam dan tidak berani menjawab pertanyaan yang diajukan oleh guru, siswa kurang aktif di kelas ini terlihat ketika siswa ditanya oleh guru, siswa tersebut tidak berani untuk menjawab pertanyaan yang diajukan oleh guru, siswa tidak berani untuk bertanya kepada guru jika mereka tidak mengerti dengan penjelasan yang guru sampaikan, siswa kurang percaya diri, sehingga membuat siswa menjadi malu dan tidak berani untuk berbicara dan mengungkapkan pendapat mereka meski mereka telah menulisnya didalam kertas, kurangnya keaktifan siswa di kelas membuat siswa menjadi tidak berani untuk berada didepan kelas, hal ini terlihat ketika guru meminta siswa untuk membaca teks percakapan didepan kelas hanya siswa yang aktif yang berani maju ke depan kelas.

Pengamatan yang peneliti lakukan di kelas IV Mis Al-Wardah Balai Karangan, untuk memperkuar hasil pengamatan peneliti juga melakukan wawancara dengan guru wali kelas IV yang mengungkapkan bahwa masih ada siswa yang malu dan tidak berani ketika berada di depan kelas, dengan alasan bahwa siswa takut dan tidak yakin dengan hasil pekerjaannya sendiri. Selain itu, beberapa siswa juga mengatakan bahwa mereka takut untuk maju ke depan kelas karena malu kepada teman-teman mereka karena akan ditertawakan, dan mereka juga malu ketika ingin bertanya dan menjawab pertanyaan yang guru berikan dengan alasan mereka takut salah.

Siswa yang kurang aktif dalam kegiatan pembelajara di kelas, maka diperlukan metode pembelajaran yang dapat membuat siswa menjadi lebih berani dalam mengungkapkan sesuatu yang sesuai dengan pemahaman mereka. Melihat usia siswa sekolah dasar yang masih termasuk dalam usia perkembangan, membuat siswa menjadi mudah dibentuk. Oleh karena itu untuk membuat siswa aktif dalam kegiatan belajar mengajar, maka dapat menggunakan 
metode Bermain Peran. Dengan menggunakan metode bermain peran ini diharapkan siswa dapat lebih percaya diri, lebih aktif dalam kegiatan belajar mengajar di kelas maupun diluar kelas dan agar siswa dapat mengekspresikan diri didepan kelas maupun didepan umum.

Berdasarkan uraian di atas, peneliti berkeinginan untuk melakukan sebuah penelitian yang berkaitan dengan keaktifan siswa dalam belajar. Karena keaktifan siswa kelas IV dalam belajar di Mis Al-Wardah Balai Karangan masih kurang. Maka dari itu penulis ingin melakukan penelitian yang berjudul "Pengaruh Metode Bermain Peran Terhadap Aktifitas Belajar Siswa Sekolah Dasar Pada Mata Pelajaran Bahasa Indonesia".

Tujuan penelitian ini adalah untuk mengetahui pengaruh metoden bermain peran terhadap aktivitas belajar siswa kelas IV MIS Al-Wardah Balai karangan.

Aktivitas menurut M. Mulyono dalam Darmadi (2017: 248) adalah "kegiatan atau keaktivan". Jadi aktivitas dapat diartikan sebagai segala kegiatan yang dilakukan baik secara fisik maupun nonfisik .

Menurut Sardiman dalam Iin Isnaini (2012: 5) aktivitas belajar adalah kegiatankegiatan siswa yang menunjang keberhasilan belajar. Sedangkan menurut Hamalik dalam Efendi (2012: 4) mendefinisikan bahwa aktivitas belajar adalah berbagai aktivitas yang diberikan kepada pembelajaran dalam situasi belajar mengajar.

Berdasarkan pendapat ahli diatas maka dapat disimpulkan bahwa aktivitas belajar adalah segala kegiatan yang lakukan siswa pada setiap pembelajaran berlangsung untuk menunjang keberhasilan belajar siswa. Aktivitas belajar yang dilakukan siswa dapat berupa kegiatan yang terjadi secara fisik maupun nonfisik.

Aktivitas belajar merupakan segala kegiatan yang dilakukan siswa pada saat kegiatan belajar mengajar. Aktivitas belajar siswa melibatkan fisik maupun mental siswa seperti aktivitas visual, aktivitas oral (lisan), aktivitas menulis, aktivitas mendengar, aktivitas menggambar, aktivitas emosional, aktivitas matrik dan aktivitas fisik dan mental (Hamalik Oemar dalam Iin Isnaini (2012: 6)). Dengan banyaknya variasi dalam aktivitas belajar, tentunya guru harus dapat melakukan kegiatan pembelajaran dengan menggunakan metode yang sesuai dan bervariasi agar pembelajaran menjadi lebih optimal dan menjadikan siswa lebih aktif dalam pembelajaran.

Peneliti menerapkan metode bermain peran dalam penelitian ini, untuk meningkatkan aktivitas belajar siswa.. Menurut H. Darmadi (2017: 246) metode bermain peran adalah berperan atau 
memainkan peran dalam dramatisasi masalah sosial ataupsikologi. Menurut Masitoh dan Dewi dalam Dalam Safitri (2016: 17) menyatakan bahwa role playing (bermain peran) merupakan permainan dalam bentuk dramatisi sekelompok siswa dalam melaksanakan kegiatan tertentu yang telah diarahkan guru. Sedangkan menurut Miftahul Huda dalam Putri (2016: 28) bermain peran adalah suatu cara penguasaan bahan-bahan pelajaran melalui pengembangan imajinasi dan penghayatan siswa.

Berdasarkan pendapat yang telah dipaparkan maka dapat di simpulkan bahwa metode bermain peran adalah suatu metode yang digunakan untuk memerankan suatu tokoh dalam sebuah cerita atau drama yang bertujuan untuk mengembangkan imajinasi siswa serta melihat penghayatan dalam mengekpresikan diri dan untuk melatih keaktifan siswa.Tujuan dari penggunaan metode bermain peran menurut Darmadi (2017: 247) adalah sebagai berikut: (1)Untuk motivasi siswa,(2) Untuk menarik minat dan perhatian siswa, (3) Memberikan kesempatan kepada siswa untuk mengeksplorasi situasi dimana mereka mengalami emosi, perbedaan pendapat dan permasalahan dalam lingkungan kehidupan sosial anak, (4) Menarik siswa untuk bertanya, (5) Mengembangkan kemampuan komunikasi siswa, (6) Melatih siswa untuk berperan aktif.

Pembelajaran dengan menggunakan metode bermain peran peneliti lakukan dengan langkah-langakah sebagai berikut:

1. Guru menjelasakan materi.

2. Guru membagi siswa dalam beberapa kelompok.

3. Guru memberikan naskah drama kepada masing-masing kelompok

4. Guru menjelaskan secara singkat tentang kegiatan yang akan dilakukan.

5. Guru memberikan kesempatan kepada siswa untuk bertanya.

6. Siswa berdiskusi

7. Siswa memerankan drama di depan kelas.

8. Kelompok yang lain memperhatikan dan memberikan komentar tetang peran yang dimainkan oleh angota kelompok lain.

9. Guru meminta masing-masing kelompok untuk menyimpulkan hasil pembelajaran.

10. Guru memberikan masukan dan menyimpulkan hasil pembelajaran secara umum.

Pembelajaran merupakan suatu hal yang sangat penting didalam proses pendidikan. Pemebelajaran merupakan interaksi yang harus dipahami oleh setiap pendidik.Setiap masing-masing mata pelajaran dalam pembelajaran pastinya memiliki tujuan yang akan ingin dicapai. Begitu juga dengan pembelajaran Bahasa Indonesia, yang bertujuan untuk membuat siswa menjadi memahami dan menguasai 
keterampilan menulis, keterampilan membaca, keterampilan menyimak, keterampilan berbicara, dan karya sastra. Dari beberapa keterampilan dan sastra yang terdapat dalam Pembelajaran Bahasa Indonesia, dapat mengembangkan dan meningkatkan keterampilan, pengetahuan , dan aktivitas belajar siswa.

\section{METODE PENELITIAN}

Jenis penelitian ini adalah jenis penelitian kuantitatif dengan metode penelitian eksperimen. Menurut Amos Neolaka (2014: 30) penelitian eksperimen adalah suatu penelitian yang berusaha mencari pengaruh variabel tertentu terhadap variabel yang lain dalam kondisi yang terkontrol secara ketat. Desain penelitian menggunakan one group design, sebelum dan sesudah memberikan perlakuan.

\section{Subjek dan Objek Penelitian}

Subjek penelitian dalam penelitian ini adalah siswa siswi kelas IV MIS AlWardah Balai Karangan, yang berjumlah 36 orang. Adapun objek penelitian ini adalah aktivitas belajar siswa kelas IV MIS AlWardah Balai Karangan.

\section{Teknik Pengumpulan Data dan Instrumen Penelitian}

Teknik pengumpulan data mengunakan angket atau kuesioner dan dokumentasi. Angket atau kuesioner merupakan teknik pengumpulan data yang dilakukan dengan cara memberi seperangkat pernyataan tertulis kepada responden untuk dijawabnya (Sugiyono, 2015:199). Berdasarkan pendapat ahli yang telah dipaparkan teknik pengumpulan data dengan kuesioner atau angket ini peneliti lakukan dengan memberikan pertanyaanpertanyaan kepada masing-masing siswa, dan kemudian siswa yang telah selesai mengisi pertanyaan-pertanyaan tersebut kemudian di kembalikan kepada peneliti.

Dokumen merupakan catatan peristiwa yang sudah berlalu, yang bisa berbentuk tulisan, gambar, atau karya-karya monumental dari seseorang (Sugiyono, 2015: 273). Berdasarkan pendapat ahli yang telah dipaparkan, dalam penelitian ini peneliti menggunakan teknik pengumpulan data dengan dokumentasi yang berupa fotofoto ketika melakukan penelitian, dan beberapa dokumen yang menunjang kegiatan penelitian yang peneliti lakukan.

Instrumen yang digunakan dalam penelitian ini adalah menggunakan instrumen kuesioner (angket). Instrumen penelitian angket ini terdiri dari 23 pertanyaan dan akan diisi oleh siswa sendiri. Terdapat alternatif jawaban dalam angket yaitu Selalu dengan skor 4, Sering dengan skor 3, Kadang-kadang dengan skor 2, dan Tidak Pernah dengan skor 1. Setelah diisi oleh siswa angket tersebut kemudian dikembalikan kepada peneliti. Instrumen penelitian dengan angket ini akan diberikan sebanyak dua kali yaitu sebelum 
memberikan perlakuan dan sesudah memberikan perlakuan.

\section{Teknik Aanalisis Data}

Teknik analisis data yang digunakan dalam penelitian ini adalah teknik analisis deskriptif kuantitatif. Analisis data statistik deskriptif menurut Sugiyono (2015: 288) adalah statistik yang digunakan untuk menganalisis data dengan cara mendeskrisikan atau menggambarkan data yang telah terkumpul sebagaimana adanya tanpa bermaksud membuat kesimpulan yang berlaku untuk umum atau generalisasi.

Data yang telah terkumpul kemudian dianalisis. Dengan langkah-langkah sebagai berikut.

\section{Menghitung Validitas Instrumen}

Rumus untuk menghitung skor validitas instrumen dengan cara sebagai berikut:

$$
\text { skor }=\frac{\text { total nilai }}{\text { jumllah item yang dinilai }}
$$

\section{Menghitung Aktivitas Siswa}

Rumus untuk menghitung aktivitas siswa menurut Masyhud dalam Nuraini (2018 : 34) adalah sebagai berikut :

$P=($ Skor yang Diperoleh $) /($ Skor Maksimal) $\times 100 \%$

Gambar3.2. Rumus Menghitung Aktivitas Siswa

Yonny dkk dalam Nurkhikmah (2013: 21).

\section{Uji Normalitas}

Uji normalitas digunakan untuk mengetahui apakah data dari hasil penelitian normal atu tidak. Untuk melakukan uji normalitas data maka dapat menggunakan rumus Chi Kuadrat.

Menurut Sugiyono (2017: 107) rumus Chi Kuadrat yang dapat digunakan adalah sebagai berikut:

\section{Uji Statistik}

$$
x^{2}=\frac{\left(f_{o}-f_{h}\right)^{2}}{f_{h}}
$$

\section{a. Uji Z}

Jika data berdistribusi normal maka untuk menguji hipotesis dapat menggunakan uji statistik yaitu uji z. Uji z digunakan bila data yang berdistribusi normal memiliki sampel yang berukuran besar ( $\mathrm{n} \geq 30$ ). Langkah-langkah pengujian menurut Lestari dan Yudhanegara (2015: 266-269) adalah sebagai berikut:

1) Menentukan nilai uji statistik (uji z)

$$
Z_{\text {hitung }}=\frac{\mu_{D}-\sqrt{n}}{\sigma_{D}}
$$

2) Menentukan nilai kritis

$$
z_{\text {tabel }}=z_{\left(1 / 2^{-\alpha)}\right.}
$$

\section{3) Memberikan kesimpulan}

Nilai $\mathrm{Z}_{\text {hitung }}<\mathrm{Z}_{\text {tabel }}$ maka $\mathrm{H}_{\mathrm{o}}$ ditolak.

\section{b. Uji Wilcoxon}

Jika data tidak berdistribusi normal maka uji statistik yang digunakan adalah uji tanda ( sign test ), Lestari dan Yudhanegara 
(2015: 275-277). Langkah-langkah pengujian adalah sebaga berikut:

\section{1) Merumuskan}

Hipotesis

Pihak Kanan

$$
\mathrm{H}_{\mathrm{o}}: \mathrm{R}_{2} \leq \mathrm{R}_{1} \text {, Aktivitas Siswa setelah }
$$

diterapkan metode bermain peran tidak

2) Menentukan nilai uji statistic

\section{Tabel 1. Tabel Membuat Daftar Rank}

\begin{tabular}{|c|c|c|c|c|c|c|}
\hline $\begin{array}{c}\text { Kolom } \\
1\end{array}$ & $\begin{array}{c}\text { Kolom } \\
2\end{array}$ & $\begin{array}{c}\text { Kolom } \\
3\end{array}$ & $\begin{array}{c}\text { Kolom } \\
4\end{array}$ & $\begin{array}{c}\text { Kolom } \\
5\end{array}$ & $\begin{array}{c}\text { Kolom } \\
6\end{array}$ & Kolom 7 \\
\hline \multirow[t]{2}{*}{$\mathrm{X}_{1}$} & \multirow[t]{2}{*}{$\mathrm{X}_{2}$} & \multirow[t]{2}{*}{ D } & \multirow{2}{*}{$\begin{array}{c}\text { Data } \\
\text { Terurut }\end{array}$} & \multirow{2}{*}{$\begin{array}{l}\text { No } \\
\text { Urut }\end{array}$} & \multirow[t]{2}{*}{ Rank } & $\begin{array}{c}\text { Rank } \\
\text { Bertanda }\end{array}$ \\
\hline & & & & & & $\mathrm{D}+$ \\
\hline
\end{tabular}

\section{3) Menentukan nilai $W_{\text {hitung }}$}

Nilai $W_{\text {hitung }}$ adalah bilangan yang terkecil antara jumlah rank positif dan jumlah rank negatif.

\section{4) Menentukan nilai kritis}

$$
\mathrm{W}_{\text {tabel }}=\mathrm{W}_{(\alpha, \mathrm{n})}
$$

Keterangan:

$\alpha=$ taraf signifikan

$\mathrm{n}=$ banyak sampel

\section{5) Menentukan criteria pengujian hipotesis}

Jika $\mathrm{W}_{\text {hitung }} \leq \mathrm{W}_{\text {tabel}}$,

maka $\mathrm{H}_{\mathrm{o}}$ ditolak

Jika $\mathrm{W}_{\text {hitung }}>\mathrm{W}_{\text {tabel, }}$

maka $\mathrm{H}_{0}$ diterima

\section{6) Memberi Kesimpulan}

$$
\text { Nilai } \quad \mathrm{W}_{\text {hitung }}<\mathrm{W}_{\text {kritis, }} \text {, maka } \mathrm{H}
$$

ditolak, artinya pada taraf Kepercayaan 95\% aktivitas siswa setelah diterapakan metode bermain peran lebih baik dibandingkan sebelum diterapkan metode bermain peran.

\section{7) Effect Size}

Effect size digunakan untuk mengetahui besarnya pengaruh metode bermain peran terhadap aktivitas belajar siswa. Rumus untuk menghitung effect size menurut Cohen dalam Fatmawati dan Utari (2015) adalah sebagai berikut:

$$
d=\frac{M_{i}-M_{B}}{\sqrt{\frac{S D_{B}^{2}+S D_{i}^{2}}{2}}}
$$

\section{HASIL DAN PEMBAHASAN}

Hasil dari penelitian ini adalah terdapat pengaruh metode bermain peran terhadap aktivitas belajar siswa, sehingga 
aktivitas siswa mengalami peningkatan. Ha : Metode Bermain Peran dapat Dari hasil analisis data menggunakan uji mempengaruhi aktivitas belajar siswa, wilcoxon memperoleh hasil Whitung diterima. Berikut adalah hasil data angket sebesar 129 sedangkan Wtabel sebesar 208. aktivitas siswa sebelum dan sesudah Dari hasil tersebut maka dapat di simpulkan diberikan perlakuan.

bahwa Whitung < Wtabel, maka hipotesis

Tabel 2. Hasil Nilai Sebelum dan Sesudah Perlaku

\begin{tabular}{ccc}
\hline & Sebelum perlakuan & Sesudah perlakuan \\
\hline Jumlah nilai & 1847 & 1961 \\
Rata-rata & 51,31 & 54,47 \\
Persentase & $55,77 \%$ & $59,21 \%$ \\
\hline
\end{tabular}

Berdasarkan data pada tabel tersebut diperoleh hasil jumlah nilai keseluruhan sebelum diberikan perlakuan sebesar 1847 , rata-rata nilai 51,31 dengan persentase rata-rata aktivitas siswa sebesar $55,77 \%$. Sedangkan hasil skor sesudah diberikan perlakuan jumlah nilai keseluruhan sebesar 1961, nilai rata-rata siswa menjadi 54,47 dengan persentase aktivitas siswa mencapai 59,21\%. Hal ini menunjukkan bahwa terjadi peningkatan aktivitas siswa ketika diberikan perlakuan pada saat pembelajaran yaitu pembelajaran menggunakan metode bermain peran.

\section{PEMBAHASAN}

Dalam penelitian ini untuk mengetahui metode bermain peran dapat mempengaruhi aktivitas belajar atau tidak, maka dibuktikan dengan menggunakan uji statistik dalam pengujian hipotesis. Sebelum menguji hipotesi dengan menggunakan uji statistik, maka dilakukan pengujian untuk mencari tahu apakah data penelitian berdistribusi normal atau tidak. Jika berdistribusi normal maka pengujian hipotesis menggunakan uji $\mathrm{Z}$ dan jika tidak berdistribusi normal maka menggunakan uji Wilcoxon. Hasil uji normalitas data sebelum dan sesudah perlakuan, menunjukan bahwa $X^{2}{ }_{\text {hitung }}>X^{2}$ tabel, hal ini berarti bahwa data tersebut tidak berdistribusi normal. Karena data tidak berdistribusi normal, maka pengujian hipotes menggunakan uji wilcoxon. Hasil dari uji wilcoxon menunjukkan bahwa adanya pengaruh saat menggunakan metode bermain peran, yaitu aktivitas belajar siswa meningkat setelah diberikan perlakuam. Hal ini dapat dilihat dengan hasil uji wilcoxon, bahwa $\mathrm{W}_{\text {hitung }}$ Senilai 129 dan $\mathrm{W}_{\text {tabel }}$ senilai 208, ini berarti $\mathrm{W}_{\text {hitung }}<\mathrm{W}_{\text {tabel }}$, sehingga dapat 
disimpulkan bahwa terdapat pengaruh ketika menggunakan metode bermain peran, yaitu aktivitas belajar siswa menjadi meningkat. Pengaruh metode bermain peran terhadap aktivitas belajar siswa sebesar 0,44 , yang termasuk dalam kategori sedang. Aktivitas belajar siswa meningkat setelah diberikan perlakuan, yang ditunjukan dengan hasil data observasi dan hasil data nilai angket sebelum dan sesudah perlakuan. Sebelum perlakuan dilihat dari data hasil angket memperoleh jumlah nilai keseluruhan sebesar 1847, nilai rata-rata 51,31 dengan rata-rata persentase aktivitas siswa senilai $55,77 \%$. Hasil jumlah nilai keseluruhan angket sesudah diberikan perlakuan senilai 1961, rata-rata nilain54,47 dengan rata-rata persentase aktivitas belajar siswa senilai 59,21\%, Dari data tersebut telah membuktikan bahwa dengan menggunakan metode bermain peran dapat mempengaruhi aktivitas belajar siswa, sehingga aktivitas belajar siswa menjadi meningkat.

Berdasarkan penelitian yang dilakukan di MIS Al-Wardah Balai Karangan menerapkan metode bermain peran dalampembelajaran, siswa tampak antusias dan semangat untuk mengikuti pembelajaran. Metode bermain peran ini merupakan metode yang melibatkan seluruh siswa dan siswa berperan aktif didalamnya. Dengan menerapkan metode bermain peran siswa akan memerankan tokoh dalam cerita. Sebelum siswa memerankan tokoh dalam cerita, pada hari sebelumnya siswa telah dibagi menjadi 6 kelompok. Satu kelompok terdiri dari 6 orang, dan pembagian kelompok dilakukan secara acak. Setelah membagikan kelompok peniliti membagikan naskah drama kepada masing-masing kelompok. Masing-masing kelompok mendapatkan cerita yang berbeda-beda.

Pertemuan selanjutnya siswa telah duduk rapi. Peneliti menjelaskan kegiatan yang akan dilakukan, dan memberikan kesempatam siswa untuk berdiskusi kepada teman satu kelompok, dalam sesi diskusi terlihat beberapa kelompok memberikan semangat pada temantemannya. Setelah berdiskusi, ketua kelompok mengambil no urut untuk tampil. Siswa terlihat sangat senang dan bersemangat, semangat mereka terlihat ketika ada beberapa properti yang mereka bawa, dan mereka memanfaatkan barangbarang yang ada di dalam kelas untuk mendukung drama mereka. Ketika menampilkan drama siswa sangat antusias dan bahkan ingin kegiatan yang mereka lakuakan direkam. Kegiatan pembelajaran menggunakan metode bermain peran membuat siswa senang, bersemangat dan antusias mengikuti pembelajaran, dan membuat siswa menjadi aktif dalam kegiatan pembelajaran. Keaktivan siswa 
terlihat pada saat mereka begitu bersungguh-sungguh dalam menyiapkan perlengkapan untuk m memainkan drama, siswa memperhatikan dengan baik ketika teman yang lain sedang memerankan drama, siswa yang pendiam menjadi mau berbicara, bertanya dan menjawab pertanyaan yang diajukan, yang malu dan tidak berani menjadi berani.

\section{SIMPULAN}

Berdasarkan hasil analisis data penelitian maka dapat di simpulkan bahwa metode bermain peran dapat mempengaruhi aktivitas belajar siswa MIS Al-Wardah Balai Karangan menjadi lebih baik sehingga aktivitas belajar siswa mengalami peningkatan, dengan nilai $\mathrm{W}_{\text {hitung }}$ Senilai 129 dan $\mathrm{W}_{\text {tabel }}$ senilai 208, ini berarti $\mathrm{W}_{\text {hitung }}<\mathrm{W}_{\text {tabel }}$ maka Ho: metode bermain peran tidak mempengaruhi aktivitas belajar siswa, ditolak dan Ha: metode bermain peran dapat mempengaruhi aktivitas belajar siswa diterima.

Aktivitas belajar siswa meningkat setelah diberikan perlakuan, yang ditunjukan dengan hasil nilai angket sebelum dan sesudah perlakuan. Sebelum perlakuan dilihat dari data hasil angket meperoleh nilai rata-rata 51,31 dengan rata-rata persentase aktivitas siswa senilai $55,77 \%$. Hasil rata-rata nilai angket sesudah diberikan perlakuan senilai 54,47 dengan persentase rata-rata aktivitas siswa senilai 59,21\%. data tersebut telah membuktikan bahwa dengan menggunakan metode bermain peran dapat mempengaruhi aktivitas belajar siswa, sehingga aktivitas belajar siswa menjadi meningkat.Besarnya pengaruh metode bermain peran terhadap aktivitas belajar siswa sebesar 0,44 dan termasuk kedalam kategori sedang.

\section{DAFTAR PUSTAKA}

Darmadi, H. 2017. Pengembangan Model dan Metode Pembelajaran Dalam Dinamika Belajar Siswa. Yogyakarta : Deepphublishing. https://books. google.co.id/books?isbn=602401939

4 diakses tanggal 20 februari 2019

Efendi. 2012. "Meningkatkan Aktivitas Belajar Siswa Dengan Menggunakan Metode Kerja Kelompok Pada Pembelajaran Ilmu Pengetahuan Alam Kelas IV Sekolah Dasar Negeri 05 Sungai Kinjil." Jurnal Pendidikan dan Pembelajaran. Vol 2, No3. http://jurnal. untan. ac.id/index. php/jpdpb/article/view/1210.

(Dibuka tanggal 13 Februari 2019.

Iin, I. 2012. Peningkatan Aktivitas Belajar Siswa Dalam Pembelajaran Ilmu Pengetahuan Alam Dengan Menggunakan Metode Bermain Peran Pada Siswa Kelas IV SDN 19. Tersedia di jurnal.untan.ac.id/ 
index.php/jpdpb/article/download/11 93/pdf.

Liana, P. 2016. Pengaruh Metode Bermain Peran Terhadap Kemampuan BerbicaraSiswa Pada Mata Pelajaran Bahasa Indonesia Kelas III MIN 11 Bandar Lampung Tahun Ajaran 2015/2016. Skripsi. Fakultas Tarbiah dan Keguruan. Institut Agama Islam Negeri Raden Intan Lampung: Bandar Lampung. (Dibuka Tanggal 22 Februari 2019)

Meti S. 2015. Pengaruh Metode Role Playing (Bermain Peran) Terhadap Motivasi Belajar Siswa Pada Mata Pelajaran Bahasa Indonesia Kelas V di SDN Cempaka 1 Putih Tahun Ajaran 2014-2015 (Kajian Teori). Skripsi.

http://repository.uinjkt.ac.id/dspace/b itstream/123456789/29248/1/METI \%20SAFITRI-FITK.pdf. Diakses tanggal 11 Oktober 2018.

Neolaka, A. 2014. Metode Penelitian dan Statistik. Bandung: PT Remaja Rosdakarya.

Sugiyono. 2015. Metode Penelitian Tindakan Komprehensif. Bandung: Alfabeta

Sugiyono. 2015. Metode Penelitian Pendidikan. Alfabeta: Bandung. 